\title{
Contemporary Afghanistan Outlook: Between Counterinsurgency and Search of the Social Contract
}

\begin{abstract}
This article is based on reassessment of the contemporary results of counterinsurgency and nation-building in Afghanistan. Nation-building initiatives have been started in the country since the Bonn agreement in December 2001. This agreement brought into reality the current governing system of Afghanistan. Counterinsurgency in Afghanistan has been initiated in full mode since 2009 after a sound success on Iraqi frontier.

However, each operational area is bringing its own specifics into play. The same was with Afghanistan. The newly established constitutional presidential republic has faced with inheritance of unresolved sensitive ethnical identity issues, confrontation between different groups for self-governing authority and security of essential resources. These preconditions have brought a diversified and even confrontational social environment into reality. Prolonged military operations in Afghanistan could show that diversified social environment and misevaluated cultural heritage has led to misleading assumptions that centralized presidential governing system could become an effective ruling model for post-Taliban country.

One of the key notions of this article is that historical lessons taught by long years of colonialist rule in Afghanistan has not been learned and misevaluation of diversified and confrontational local entities has brought another historical lesson of Afghan tribal resistance. More than that, diversified and confrontational entities of Afghanistan have not been a favorable subject for possible social contract. The term social contract was introduced as explanatory method of national political behavior and systemic structure by Jean Jacques Rousseau in 18th century Europe. Afghan society has become the subject to this model of political philosophy only as counterinsurgency campaign gained full capabilities around 2009. Reassessment of long term nation building efforts in this article is based on evaluation of Afghan social contract's progress.
\end{abstract}

Keywords: Afghanistan, Afghan entities, nation-building, counterinsurgency, social contract, Hamid Karzai.

\section{Introduction}

The contemporary Afghanistan could be described as the country facing with the longest operational intervention from the U.S. and Allies in modern history. The combat operational mode has been officially terminated on 31 
December 2014. Never the less, Afghanistan is still considered as the example of shaky and grim efforts of nation-building. Some reports and images of the mass media have brought triumphant achievements as Afghan national authorities were consecutively overtaking responsibility for security and stability in provinces and towns across the country. More than that, the first democratic change of political power has been conducted in the history of Afghanistan in summer 2014. Under these circumstances one could remember the grand mission declared by the president George W. Bush in the fall 2001 that has called for: "democracy for Afghanistan, Marshall Plans for

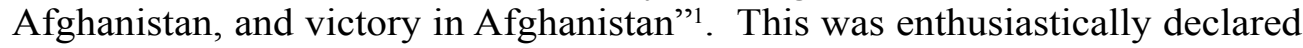
after the successful initial military campaign against the Taliban regime. More than thirteen years have passed since then. The contemporary results of that grand mission in the conflict-torn Afghanistan are still quite unstable.

The opposing reality is hitting us with increasing casualty numbers of Afghanistan national armed force soldiers facing Taliban fighters on their own lead. More than that, terrorist attacks have been drastically increasing in Kabul and other major Afghan towns throughout 2014. Even the symbolic closing ceremony of ISAF has been conducted in modest and restricted way due to security precautions.

This article should be considered as reassessment of achieved results as the demanding and ambitious task of nation-building has been conducted on Afghanistan frontier by many Western allies for more than dozen years. The objective of this article is to provide evaluation of current progress of nationbuilding and development of democratic governing system in Afghanistan. This is done by taking two important tasks that would be highlighted in different parts of the article. The first task is to define a specific diversified social and cultural environment that has been the foundation for Afghan nation-building efforts. The second task calls for assessment of multiple development progress that should be defined in effectiveness of governing system and solutions suitable for local social environment. That is why a descriptive method of social contract model, traditional model of political philosophy, is taken seriously into account.

In order to achieve an analytic objective, the most relevant tools need to be chosen. It is obvious that counterinsurgency efforts and establishment of centralized governing system has been the basic occupation of Western players in Afghanistan for the last thirteen years. That is why the comparative analysis of Afghan social-political system with efforts and nation-building effects led by external players would serve the main objective of the work. For the purpose of the comparative analysis this article is divided into two parts. The first part is dedicated to highlight inheritance of the Afghan multiple socio-political structure and specific religious - based culture. This part of the article highlights essential factors of social and tribal diversification that should have been assessed as standing assumptions of the initial, post-Taliban, 
nation-building scenario. The second part of the article shifts attention to assessment of nation-building efforts already conducted in Afghanistan. All these efforts led by external players in order to develop nation-building and ouster Taliban supporters in the country have had certain affects on the defined goal - stable and prosperous Afghanistan. The definitive model of social contract would be serving as evaluation tool of counterinsurgency and nation-building efforts in contemporary Afghanistan.

Finally, key areas of interest should be stated prior the initiation of the analysis. First of all, a deeper understanding of Afghan society and its social, cultural and political behavior must be considered in connection to conflicts that have been devastating the country for more than 30 years already. That is why a dominant material for Afghan socio-political analysis is taken from the period of 2009-2011. This was the period of surge in military and diplomatic efforts in Afghanistan that has brought a lot of analytic attention to prolonged problems of that country. Secondly, certain definitions of inner circles and external players should be described. "Inner circles" in this article should be defined as tribal groups, warlords and influential power-brokers that are constantly taking part in a gambling game of power between central government of Kabul and Taliban affiliated groups. What is more, "external players" in this article are highlighted as the U.S. - led governmental institutions, military forces and their allied counterparts that had been initiating a pre-defined framework for rebuilding Afghanistan since December 2001.

\section{Afghan inheritance}

Any comparative analysis should be started with a definition of comparing elements. In case of Afghanistan development a comparative logic would lead to definition of religious-cultural and social environment that has been formed through centuries with a certain mixing of Islamic traditions and tribal cultural inheritance. All the traditional defining elements of Afghan ethnic diversity and a certain social environment are discussed in the first part of this article. More than that, the main task for this part is to define post-Taliban social and cultural environment that initially has been a precondition for facilitation of nation-building efforts. That is why a more detailed orientation of social environment and cultural heritage that have been affected by long years of colonialist rule would serve the main task of the first part.

\section{Afghanistan's socio-political orientation}

Ethnic tribes inhabiting the land of Afghanistan have been struggling for survive during the course of the history. These efforts have been made 
not only for countering geographical conditions but for making alliances to survive on political and military fields as well. Afghanistan lands are inhabited by people who are used to war atrocities and pragmatic inter-tribal coalitions (Guest 2011). There are seven main tribal groups populated in the lands of contemporary Afghanistan: Pashtun, Baluchi, Turkmen, Tajik, Uzbek, Aimak and Hazara. There are some more small tribes but they are not significantly influential in any particular region of the country. The majority of the population consists of Pashtu tribes that inhabit regions in south and east of Afghanistan along the Pakistan border. The northern part of the country is dominated by Tajik and Uzbek tribal groups (Tanner 2009, p. 5-7). More than that, the central part of Hindu Kush mountains could offer a mix of these tribal groups with influential territories of Hazara, predecessors of ancient Mongols, controlling Bamyan province in that part of the country.

Another important element of the mixed tribal society is the segmentation of Islam religious groups. Around 80 per cent of local population is Sunni Muslim that is a dominant religious group among Pashtu and Tajik, two the most dominant ethnic groups around the country area (CIA World Fact Book 2014). Shia Muslims are mostly dispersed in western part of the country next to Iranian border. This segmentation illustrates another potential trouble as the religious sectarian violence has been a dominant issue in Middle East in last twelve years.

The political culture is another major element of Afghanistan society. During the long historical time frame all local diversified groups have been enjoying a participation in their own decision making processes. To put it in other words, local level governing system is based on tribal groups' elders' participation and responsibility for decisions based on immediate needs and problems of local groups. This low - level participation mechanism in governing process has been the important factor that was kept in effect even during sultanistic periods of Afghan history (Tanner 2009, p. 109).

Considering the contemporary political system of the country, it should be mentioned that Islamic Republic of Afghanistan is a unitary republic ruled according to the presidential democratic model (Constitution of Afghanistan, Articles 1, 2, 60). Such a political model was implemented according to the Constitution of Afghanistan ratified in 2004. The biggest challenge in this governing system lies in between a proper form of participation in decision making process: decisions of representatives or the traditional participation in decision making on low-level local governing bodies. This challenge of the governing decision making has been following nation-building efforts in Afghanistan since the initial military victory against Taliban regime. There is a significant differentiation among Afghan tribal groups that had to be assessed prior initial nation building efforts in post - Taliban period. Difficult political and cultural issues of this segmented nation need a more detailed definition for the further comparative analysis. 


\section{Heritage of colonialism}

In case of Afghanistan, the colonialism could not be understood and applied as in most cases of the Middle East countries. The reason for that is simple. Afghanistan has never been fully occupied and controlled by any hegemonic power. Some authors might disagree with this fact suggesting that biggest urban areas and the most important trade lines were constantly controlled by different foreign empires (Barfield 2011, p. 54-65). The truth is that such a control had never been fully implemented over the population. The population is the key factor of any effective control - the truth that has been repeatedly highlighted by hard lessons of military campaign in the country since the fall of Taliban. Even earlier examples of population factor could be borrowed from Anglo - Afghan wars fought in the 19th century. British attempt to dominate over Afghani population and control of governing system has ignited three consecutive wars in the country. What is more, British geopolitical interests have brought the creation of Durand Line separating British - loyal Pashtun tribal areas from war oriented and occasionally united "rural peasants" (Guest 2011). This is clearly the most significant outcome of long term colonialist interests that has been affecting difficult efforts of counterinsurgency and nation building on the grim front line in between Afghan and Pakistani tribal areas.

As the 19th century has brought an official separation of long time common tribal lands, the beginning of the 20th century has initiated turbulent sociopolitical experiments applied among Afghan elements of society. The third and the final Anglo - Afghan war was fought in 1919. After that war Britain officially lost any possibility of Kabul decisions' political control (Guest 2011). The new king Ammanulah Khan has initiated a radical social experiment. His initiative was to form a modern and secularized western style society in Afghanistan. The consequence of such a radical step was that many opposing groups saw such a rule as another British style political will (Tanner 2009, p. 218). More than that, many tribes were united under the idea of defense of traditional Islam norms. Soon a civil war broke in Afghanistan and the "radical ruler" was forced out from power.

Another similar social - political experiment was initiated in Afghanistan in 1978 soon after the communist party took power in Kabul. Again the defense of traditional Islam norms has played a strong role in the mobilization of the society. Tribes, predominantly Pashtuns in southern and eastern areas of the country, rose once again to oppose secularization ideas and collectivization attempts. The defense of the traditional way of life in Afghanistan soon developed into the international jihad. In this way the aggressive colonialist approach by a foreign player, in this case the Soviet Union, was met by a bloody and sacrificing resistance of diversified Afghan tribes that have been reluctant to traditional Islamic notions and low-level local tribal interests. 
Artificial separation of tribal lands followed by the two named social political experiments conducted in Afghanistan during the 19th - 20th centuries could have set preconditions for initiatives in the contemporary post-Taliban country. Earlier attempts were closely alienated with negative influence by foreign actors. These political attempts had violated traditional norms, religious dominance and traditional law. The colonialist heritage clearly suggests that the success of the current socio-political experiment run in Afghanistan by many international actors is highly dependent on the tolerance of traditional religious, cultural norms and interests of diversified tribes.

\section{Influence of religion and law}

During the fight against the Soviet invasion radical religious norms started to spread across Afghan society. Generally speaking, the announcement of jihad and conduct of it should be identified as a rapid process of religious radicalization. This process was influenced by a radical Salafism doctrine originated in Saudi Arabia, the Islam state-actor which has played a great role in Afghan jihad (Denoeux 2002, p. 61). The later cooperation between Al-Qaeda and Taliban regime could be named as a logical succession of this radicalization.

The influence of local religious leaders is still very evident in contemporary Afghanistan. This influence is implemented through mullahs' abilities to spread public opinion oriented towards religious-protectionism and highlight misconduct of traditional norms by any foreign actors. The author of these lines had a possibility to realize the seriousness of this mullahs' role in April 2011 when the message of burned Quran by a pastor in Florida has initiated wild protests across many provinces in Afghanistan.

What is more, the warrior tribes had developed their own approach to religious tradition. There is one important feature of religious tradition that separates Afghan society in comparison with many other traditional Muslim societies. This feature is the complex diversity of traditional Shariat law and Pashtunwali ethnic code. Pashtunwali is the traditional ethnic code originated in Pashtun tribal areas but quite common in other provinces as well. This ethnic code is based on three basic principles: honor (so called nang), hospitability (melmastya) and revenge (badal) (Guest 2011). More than that, common understanding of honor and revenge which is often associated with "an eye for an eye" expressions is widely spread among all Afghan tribes (Guest 2011). Traditional honor and sense of revenge should be associated with historical Afghans' tradition to re-unite in face of foreign attempts to control tribal areas. The external control is usually evaluated as the act of devastation of tribal freedom and honor.

Taliban regime which originated in southern Pashtun dominated province 
of Kandahar was strongly influenced by Pashtunwali norms. More than that, Taliban authorities have had united these norms with Shariat law. Direct interpretations of Quran and the aim to promote a pure Islamic way of social behavior are definitive points of this Islamic fundamentalist movement (Tanner 2009, p. 224). Taliban has also achieved some additional features that brought it the definition of "fundamentalism gone mad" (Denoeux 2002, p. 67). These features were the absolute ignorance of women's role in society, public punishments for violation of Islamic norms and preventive sanctions like "beard patrolling".

Another important feature of Taliban rule was that the regime was concentrated on the lower level of society. The main objective of this group was to win popular support. This was done in most provinces by securing the interests of local groups and bringing the needed Shariat justice in times of civil war anarchy. This way of behavior by addressing and promoting needs of grass-roots society differs from the contemporary regime of Afghanistan central government. Reports have been published stating that in some eastern and southern provinces of Afghanistan people were eager to ask for solutions of disputes at unofficial courts established by local religious and war leaders (International Crisis Group 2011, p.16-17). This example shows that customary law and religious norms are deeply grown into society. On the other hand, the existence of unofficial tribal courts highlights that legal governing institutions are facing with difficulties among low-level social and ethnic groups. These difficulties might be caused by cultural context of law and religious norms that are inherited by diversified society. More than that, local-level dispute solving tradition could be named as favourable precondition for growing support to power-brokers and forms a background for corruption precedents (Katzman 2015, p. 13-14, 38). Administrative and legal capacities of the central government have decreased in Afghan provinces after more than twelve years of the administrative development. This is an important circumstance that brings success and effectiveness of the current governing model under question.

\section{Evaluation of progress in contemporary Afghanistan}

As the first part of this article has highlighted complex and segmented social conditions of the population of Afghanistan, the next part of the work is designed to bring attention to provoked development of a new form of sociopolitical life of diversified Afghan society. Initial restructure of post-Taliban Afghanistan has been provoked by external players with exile political figures playing as a legitimate tool for the process. This process, however, was short of evaluating core complexity of tribal entities with dispersed interests and social, cultural - religious norms. What is more, cultural - religious norms 
have been forming some core values of the low-level social structure that should never have been ignored.

It is the right time to assess the progress of nation building in contemporary Afghanistan as the first democratically defined presidential term has expired and active military involvement in counterinsurgency efforts is being reduced. So, the second part of the article shifts attention to nation-building efforts that should be evaluated through the indication of society consolidation and governing effectiveness. This piece of work is providing a reader with evaluation of current governing system and challenges it might face after the term of Hamid Karzai presidency. What is more, an assessment of counterinsurgency as the leading element of nation building efforts would provide a better evaluation of progress in transformed Afghanistan as more than thirteen years have been spent in costly and demanding military involvement by international community.

\section{Reflections from the period of Hamid Karzai}

The period of Hamid Karzai presidency should be named as the period of central government's consolidation. This was a long presidency that followed immediately after the austere of Taliban in early 2002 till the end of the second term of presidency in summer 2014. This prolonged period of local government consolidation was marked by decreasing mutual cooperation in between the central government of the country and external players of the U.S. led coalition. Afghan Central Government and the U.S. diplomatic corps in the country have been accusing each other of broad corruption and incompetence or the backside dealing and promotion of conspiracy-based foreign policy respectively (Mashal, 2014).

It is essential to emphasize, that the democratic political order in Afghanistan was started to be implemented after a 20 years period of war. This important factor is illustrating that potential confrontations among different groups were still a dangerous issue that could have decreased effectiveness of civil society formation. Traditional understanding of democratic rule suggests that civil society is the necessary precondition for democratic consolidation. This precondition has not had any firm background at the time of Taliban crackdown. The previous part of this article has clearly described the complexity of mixed tribal interests and cultural religious norms that have been driving the social behavior for a long term. That is why the presidential term of Hamid Karzai has brought fundamentals for consolidation of new governing system that still needs to be adapted to Afghan social realities.

Hamid Karzai's presidential term should be evaluated through the prism of development of governing system. Long run of Afghan history has been exercising a variety of governing forms from free tribal authoritarian rule 
to totalitarism of the Taliban religious group, the presidential democratic governing system is a new governing model for this society. It has been developed since the Bonn Conference held in 2001 under the initiation by the U.S. Administration and some other international actors. The Conference was aimed at legal authorization of Afghan Interim Authority - the governing form with principle guide line suggesting that only the winner side against the Taliban rule was granted the de-jure status for the participation. Winners in that case were selected representatives of Northern Alliance and Afghan exile activists. Any option concerning the involvement of Taliban representatives was excluded (The UN Agreement on Provisional Arrangements in Afghanistan, December 2001). The classical approach of negotiations dictates that all major power brokers of each conflict should be invited at the negotiation table to reach a possibility of constructive agreement. But this was not the case for the political procedures following the Bonn Conference. A moderate political figure has been chosen from dominant Pashtun tribes to lead the new presidential governing efforts (Mashal, 2014).

Thus, the contemporary constitutional structure of Afghanistan should be defined. The Afghan president is elected at free general national elections for a no longer period than two cadencies. One presidential cadency could last for five years (Constitution of Afghanistan 2004, Article 62). The Afghan President has a broad influence over other political institutions. The President has a right to appoint members of the Ministers' Cabinet, judges of the High Court, Governors of provinces and districts. More than that, chiefs of provincial security institutions are appointed by the President too.

The presidential influence over the legislative body is quite strong too. The Parliament (the National Assembly) of Afghanistan consists of two houses: an upper house called Meshrano Jirga (or House of People) and a lower house Walesi Jirga (House of Elders) (Constitution of Afghanistan, Article 82). One third of 102 Meshrano Jirga members are appointed directly by the President for the period of five years (Katzman 2011, p. 5). The other part of House of Elders members is appointed by Provincial Councils. Only members of Walesi Jirga are elected during free, general and direct elections. The Presidential influence over the National Assembly is implemented by significant quantity of personal appointees to House of Elders. All legislative decisions must be passed on the mutual agreement of both houses (Constitution of Afghanistan 2004, Article 93). That is why the part of appointed representatives plays a significant role in promotion of presidential position for any possible political decisions.

Such a political model was opposed by members of the Northern Alliance. Some ethnic tribes were supporting a stronger position of the Prime Minister. The shift of governing power between the President and the Prime Minister has taken place after 12 years of consolidation of the governing system. This new shift in power would decrease presidential ability to get into government 
departments' areas of responsibility and maintain informal control of many governing matters or development processes (Mashal, 2014). This inclusive approach to governance has been exercised by the president Hamid Karzai. To tell the truth, this governance approach could be relevant to tribal chief and stands as enabling factor for promotion of selective tribal interests to Central Government agendas. More than that, this style of governance has excluded sovereign right of Provincial and District Councils to elect Governors independently and consolidate the institutional way of promoting low level interests (Katzman 2011 , p. 3-4). That is why the capability of Central Government to represent district level interests becomes quite questionable. Governors appointed by the President might be not respectful members of local communities. And respect means a lot among those complex tribal entities.

What is more, the role of political parties is grim in Afghanistan too. To tell the truth, parties could be identified as groups of supporters of political leaders or opposing actors. Their role in the political process should be based on representative principles according to differing political ideologies. Anyway, this is not the case in Afghanistan. This country is facing its own political development path with a lack of institutions that could implement political participation among society. That might be one of the reasons why the first historical democratic change of governing elite in Afghanistan has been conducted with some considerations of fraud, manipulation and backstage dealings (Mashal, 2014). Even the president Hamid Karzai has stated that "representation model in democratic system is not working properly in Afghanistan" (Karzai, 2014). This quite a pessimistic assessment stated just a few months prior the end of the president's final term reveals frustration and lost opportunities among local political elite.

To sum up, the contemporary Afghan political system has quite significant disadvantages. The most significant of these disadvantages is the lack of parliament control over executive branches. There is a dominant presidential influence on legislative initiatives of the National Assembly that highlights political functions of the governing structure. On the other hand, provincial and district interests are not so effectively achieved by the Central Government as it could be done by sovereign councils and their elected governors. This is an important factor if to bear in mind the traditional claim of freedom by different tribes of Afghan soil. As it was mentioned above, President Hamid Karzai has made a pessimistic assessment about this issue even after more than a decade spent in the office. The initial governing model of the presidential democratic republic has been shifting towards the model of presidential authority limited by cooperation of certain internal circles but not enabled by well functioned legislative democratic institutions.

Finally, the functional structure of Afghan political system of the president Hamid Karzai period could be named as another socio-political experiment initiated by external players. This time the experiment has more chances to be 
a continuous project of socio-political consolidation of Afghan tribal entities. With the recent shift of powers between newly elected President Ashraf Ghani and the Prime Minister Abdullah Abdullah there could be an initial shift towards open participation capabilities at legal institutions for low-level social groups. This is a much needed path of socio-political development that could lead to establishment of the social contract. Nevertheless, the contemporary constitutional structure of the Afghan governing system is based on 1964 constitutional norms that should be assessed as a foundation for centralized constitutional monarchy (Shurkin 2011, p. 9). This is not the best solution for such a diversified social environment that authorities led by President Hamid Karzai had inherited. The next chapter is the clear illustration of current loss of moment for social contract in Afghanistan.

\section{Counterinsurgency revisited}

Counterinsurgency has become a leading expression that defines long-term military operational goals in Afghanistan. This prolonged military campaign would require a separate analysis of all advantages and disadvantages that two different Administrations in Washington have brought to Afghan frontier. Counterinsurgency is long-lasting broad campaign with possession of multiple international tools that has a paramount role for the near future success or failure in Afghan nation-building. However, this part of the article is aimed at the highlight of principal factors of counterinsurgency campaign that could have helped the social groups of Afghanistan to advance towards a sociopolitical consolidation.

The essential purpose of contemporary counterinsurgency campaign has not changed since the original struggle of French forces over its colonial territories in the middle of 20th century. The effectiveness of counterinsurgency should be defined by complex efforts aimed to facilitate local social groups. As David Galula, the classic theorist of counterinsurgency has put it, the majority of counterinsurgency efforts consist of political initiatives and only minor efforts are based on war fighting" (Galula 1964, p. 69-70). The biggest aim of counterinsurgency is encoded not in destruction efforts of adversary groups but in positive control of holding territories and residing local communities. The contemporary U.S. military doctrinal approach would name the model of positive control as "clear, hold, and build": clear the insurgents, hold the area, and build services and support (Kaplan 2013, p. 81).

A more detailed definition of the suggested model of positive control could reveal efforts of socio-political consolidation. The positive control in counterinsurgency terms is aimed at protection of interests of local social groups. Protection of these interests is best performed by promotion of it through local governance. This process would provoke a positive association 
with new governing regime and increase reliance to newly established governing model. Interests based association to and reliance on new governing system would form the essence of the positive control in Afghan environment of diversified social entities. As the past twelve years have shown, this task is not the easy one.

There are four main goals that form the essence of the positive control: show of presence for the establishment of preventive security, identification and security of social groups' interests, development of information campaign, and establishment of legitimate governance and services (Counterinsurgency Field Manual 3-24, 2006). All these goals of counterinsurgency campaign should be evaluated in order to make the progress assessment in contemporary Afghanistan. The first of them is concerned to be a clear military approach. It could be defined as the modern military objective of clearing and holding areas out of adversary's control. In case of Afghanistan conflict this was a long scenario of multiple force activation. The initial military victory over Taliban was followed by degraded operational efforts and after that there was a strong necessity to perform the surge campaign against rebuilding dominance of Taliban affiliates. More than that, military forces currently have been switched to degraded combat role with primary mission of training and mentoring Afghan national security forces. Nevertheless, upcoming role of external forces has not been predefined yet and various operational options could be pronounced.

Secondly, the prolonged military intervention in the country by coalition forces has been affecting positive relations with local groups. This seems to be one of the possible reasons of mutual mistrust of previous president Hamid Karzai and the U.S. led coalition representatives as well (Eikenberry 2013, p. 64). Traditionally, there is a risk that a prolonged administrative control in hands of military commanders could provoke mistrust and resistance among social groups (Galula 1964, p.64-66). Thirdly, the conduct of information campaigns has made a great effort by promoting overall counterinsurgency objectives in Afghanistan and global arena as well. These efforts were especially effective during the surge campaign as the drastically increased numbers of coalition troops have been justified by Washington and other political capitals of coalition partners not only to Afghan Central Government but their respective democratic societies as well.

What is more, the active surge and its supportive campaigns had not been meant to last for an open-end period. Sooner or later, the security and governance responsibility has to be assumed by Afghan authorities. This moment has arrived in 2014 as all main counterinsurgency elements has fallen in hands of Afghan Central Government. The effectiveness of this responsibility should be revealed at least by the end of 2016. Nevertheless, the U.S. general David Petraeus, the leading commander of counterinsurgency campaigns in Iraq and Afghanistan, has previously made some significant 
remarks on problematic counterinsurgency results in Afghanistan. The General has referred to Galula's book's chapter called "The Prerequisites for a Successful Insurgency" (Galula 1964, p. 13-30). The conditions it describes include a weak or corrupt government; a neighboring country that offers safe havens; a predominantly rural, illiterate population; and a primitive economy (Kaplan 2013, p. 88). These are the traits that Afghanistan was associated with during the long period of Hamid Karzai's presidency.

To sum up, counterinsurgency campaign has created only a limited positive control among complex social entities in Afghanistan. The main goal of this campaign should be stated in consolidation of legitimate and influential local governance system. The reality of Afghanistan dictates that the influence of Central Government is still under consolidation, especially in eastern and southern regions. This process might have been interrupted by initial misconduct of military operational involvement, shift of interventional priorities and loss of momentum of the positive control in Afghanistan. However, the effective legitimacy of the governance would rely on recognition and affiliation by local social entities. That is why all these years of counterinsurgency efforts in Afghanistan should be considered as a starting point towards the social contract among diversified local social entities.

\section{Long way towards the social contract}

The diversity of ethnical and tribal entities in Afghanistan is a significant cause of decreased counterinsurgency effects. In fact, it has been the source of instability among Afghan tribes many decades before the military campaign against the Taliban rule (Tanner S. 2009, p. 238). The reason for decreased post-Taliban state consolidation is encoded in these diversities that have not been evaluated well prior the military campaign. More than that, multinational counterinsurgency efforts have been performed for many years based on misleading assumptions. The first misleading assumption has been based on possible stability in post-Taliban Afghanistan. Instead of this, a religious radicalization, growing influence of religious leaders and appealing to tribal leaders or war lords arise. These indicators have been present even in 2011 as the military surge campaign has reached its peak (International Crisis Group 2011, p. 6-8). Secondly, the Central Government was addressing these governance malfunctions by mostly blaming the escalation effects on coalition military presence during the presidency of Hamid Karzai. This clearly illustrates that the second misleading assumption, suggesting that Afghanistan Central Government would act according to proposed political - military strategy, was faulty too.

The named misleading assumptions have been based on wrong cultural and political situation awareness in Afghanistan. The core problem that led to 
the rise of Taliban is a prolonged period of wars and atrocities that brought instability among diversified social entities. To put in other words, there was a lack of a social contract among ethnic or tribal entities in Afghanistan even decades prior the Taliban rule. The lack of the social contract means that there were no historic nation building attempts in this wide community. Arguably, such an attempt could be defined during the period of the constitutional monarchy from early 1930's till early 1970's (Guest 2011). But this was a short consolidation effort that has been followed by overlapping war periods. In comparison to the constitutional monarchy period, the contemporary democratic regime in Afghanistan could be evaluated as the next socio-political experiment on its early stage.

It should be highlighted that the lack of the social contract is one of key factors that is influencing execution of positive control by governing authorities over social entities of Afghanistan. The lack of social contract in this country could have been influenced by three historical anthropological reasons. First of all, there has been no traditional psychological identification of a common Afghan group. Stephen Tanner has declared it correctly saying that: "... Afghan is simply someone who comes from Afghanistan. The term now includes ethnic Pashtuns, Turks, mongoloid Hazaras, redheaded Nuristanis brown-skinned Brahui, and number of other groups" (Tanner 2009, p. 8). Secondly, Afghan ethnic and tribal diversities have never been minimized by any long lasting political will. Insufficient political unification could be caused by a harsh terrain and difficulties to set control of such lands during old ages. The third reason comes along with the claim of freedom of the will. Separate tribal groups have been developing strong sense of honor (nang) when enjoying freedom and the pragmatic practice of cooperation under the aim of revenge ( $\mathrm{badal}$ ) once their freedom has been devastated by neighboring groups or foreign forces. Under such circumstances there were almost no practical solutions for a broad unification and nation building attempts.

There is no easy solution for the facilitation of the social contract in contemporary Afghanistan. Wide range of multinational nation-building efforts has been implemented for more than ten years already. Nevertheless, the final result of the governance consolidation is dependant only on local social entities themselves. In that case the essential question of legitimate and influential government of Afghanistan is raised again. A lot of resources have been put into research of this problem during the surge of counterinsurgency campaign. One of the most outstanding results would come from the leading American think-tank called the National Defense Research Institute, also known as the RAND Corporation. The think-tank has provided a relevant analysis for the U.S. Marine Corps intelligence activities back in 2011. This analysis has suggested that a subnational level governing system is the core solution to expand legitimacy and influence of local government system in Afghanistan (Shurkin 2011, p. 5-6). This suggestion is based on capabilities to participate 
in local level decision making and strongly supports the traditional sense of honor (nang) among social entities. Nevertheless, sub-national governing capabilities still need to be implemented on institutional level as of 2015 . This trend illustrates that a right momentum for the social contract could have been lost and Afghanistan is not facing a unifying solution after the presidential term of Hamid Karzai.

Finally, the contemporary socio-political experiment named as Islamic Republic of Afghanistan could still become a successful attempt. For this purpose some additional decisive measures should be implemented. First of all, the traditional cultural norms and customary law should be included into the nation-building process. This could be a strong consolidating factor that would make today's attempts different from what the pro-communistic regime was trying to implement in late 1970's and 1980's. What is more, the interests of lower level social entities should be taken into account in order to achieve better results. Institutional tool for this could become district councils that should be able to rise and protect interest of lower level social entities. This solution could be named as the first step towards the implementation of working model of the participation democracy.

The political philosophy of the participation democracy could be named as the grand vision of the former president Hamid Karzai (Karzai 2014). This vision could provoke a motivation for political activism of local groups and prevent the possibility for violation of their honor (nang) once serious decisions are made without them. However, there were no any district council elections held in the country since the establishment of the constitution that is based on constitutional norms of constitutional monarchy back in 1964 (Shurkin 2011, p. 4-5). More than that, significant national elections have been conducted for provincial councils in 2009 and parliamentary seats in 2010 . District level positions are usually occupied based on personal appointments of provincial governing authorities or corrupt dealings among power brokers (Biddle 2013, p. 51, 54). The lack of established institutional legitimacy of participation democracy of diversified social entities on district level has led to creation of "line ministries" that expand to district level offices instead of creating lower level decision making institutions (Shurkin 2011, p. 5-7). The prolonged counterinsurgency effort is revealing that this is insufficient foundation of the current Afghan governing system that decreases central government's influence and legitimacy among lower level social entities. More than that, multilevel ministerial foundation opens the possibility for corruptive dominance over significant resources or consolidation of decision making capabilities (Shurkin 2011, p. 8-9). This trend has clear historical attributions to influential gains of bureaucratic power brokers in post Soviet countries in mid 1990's.

Finally, it should be stated that any success of social contract would strongly depend on performance of the current political elite of Afghanistan. The 
base for this success has already been set with a peaceful change of main political positions according to constitutional principles. This was a historical moment for Islamic Republic of Afghanistan marking constitutional change of presidential cadencies and further consolidation of democratic political system. Change of governmental consolidation with diversified responsibilities of newly elected President Ashraf Ghani and the recent appointment of Prime Minister Abdullah Abdullah could be another significant milestone on the road towards the social contract.

Afghans currently are facing a systematic change of top level governing institutions that should distribute decision making capabilities among diversified tribal entities and set the way for possible peaceful political development beyond the time line of 2015-2016. This time line is important as it reveals implementation of decreased foreign military role in the country and sets local governing authorities on the path towards promotion of stability and political development in their country. The promotion of political parties' role could help significantly in that matter. Parties should be organized as active bodies of political participation involved in promotion of regional ethnic, social and unification ideas. Only the active role of political parties could lead to the development of political society. That process could be implemented during the long-term but only if sufficient steps in promotion of regional political participation, increased political will and participation of diversified entities will be achieved. As the international community has already set a possible time line for decreasing involvement in Afghanistan, their strategic success now will largely depend on central government's progress in facilitating a solid social contract among diversified Afghan groups. What is more, this time any attempts of negotiations should not exclude affiliates of Taliban. If these consolidation efforts fail there is no guarantee that multinational air forces will not execute missions over Kandahar or Kabul once again.

\section{Conclusions}

This article has highlighted main diversities that have been shaping Afghan social map many decades prior the establishment of Islamic Republic of Afghanistan. This newly established constitutional presidential republic has faced with inheritance of unresolved sensitive ethnical identity issues, confrontation between different groups for self-governing authority and security of possible material, agricultural or infrastructure resources. These preconditions have brought a diversified and even confrontational social environment into reality. As the first part of the article has highlighted, diversified social environment and misevaluated cultural heritage has led to misleading assumptions that centralized presidential governing system could become an effective ruling model for post-Taliban Afghanistan. Historical 
lessons taught by long years of colonialist rule have not been learned properly despite of Great Britain's and Soviet Union's bad experiences with Afghan tribal resistance.

These harsh colonialist lessons should highlight another important factor. Diversified and confrontational entities of Afghanistan have not been a favorable subject for possible social contract. The term "social contract" was introduced as explanatory method of national political behavior and systemic structure by Jean Jacques Rousseau in 18th century Europe. Afghan society has become the subject to this political philosophy model only as counterinsurgency campaign gained full capabilities around 2009.

In Afghan case the model of the social contract should be considered as a forceful external attempt to bring new social structure to local social entities. History of colonialist attempts and resistance has been repeating once again. This time the model could be implemented only if religious, cultural and social norms of the society would be assessed. The success of the contemporary socio-political experiment in Afghanistan is strongly dependant on prevention of the resistance fighting tradition that comes along with a centuries-long Afghan history. What is more, the radicalization of the resistance fight has brought some long-standing negative influence to the society. The rise of the radical Taliban regime and its confrontation with the Northern alliance is the main illustration of this devastating confrontation. What is more, such a militarized social behavior is the factor that needs to be prevented in contemporary Afghanistan as different groups in the Great Middle East claim their affiliation to radical movement of ISIS.

The second part of this article has revealed that prevention of radicalism in Afghanistan could be achieved only by a wide range of internal political dialogue initiatives. On one hand, contemporary nation-building initiatives should be based on respect to religious traditions and customary law as well. On the other hand, the promotion of fundamental religious directions should be avoided by any political participants as such an attempt could provoke a new wave of internal confrontation.

The best way to avoid possibilities of religious fundamentalism or radicalism is the expansion of political participation capabilities. Former Taliban representatives should not be excluded from political processes as it was done in December 2001. More than that, their involvement to decision making should be concerned as a great motivating factor that could lead to certain diversification among Taliban supporters weakening this insurgency movement. This proposition would be based on a deep-rooted sense of honor (nang) and pride shared by different Afghan groups once their self-decision making needs are satisfied.

Finally, the peaceful constitutional change of political power has brought some fresh hope that Afghan society is standing on the correct path of nationbuilding. Peaceful change of political elite post Hamid Karzai should be 
assessed as a successful exam of nation-building possibilities. However, initial diversification of political power between the President and the Prime minister has been performed not without active efforts of external diplomatic officials. Those officials had their right to act concerning the long lasting counterinsurgency campaign supported by generous international donation programs. What is more, the continuous facilitation of the social contract in Afghanistan could be based only on inclusion of Taliban affiliates into political dialogue and promotion of political parties' role. These are essential steps that would serve to formation of political society in the longer term. As it was stated previously, traditional counterinsurgency elements are based on political initiatives. Now it is the definitive moment for Afghans to step in with their political initiatives in order not to lose momentum for possible social contract that has been brought to them by international counterinsurgency efforts in that conflict-torn country.

\section{References}

Agreement On Provisionl Arrangements in Afghanistan Pending the Re-Establishment of Permnent Government Institutions, the UN Agreement signed December 5, 2001. Available at: <http://www.un.org/News/dh/latest/afghan/afghan-agree. htm $>$ [Accessed 2 July 2015].

Barfield T., 2011. "Afghanistan's Ethnic Puzzle“, Foreign Affairs, volume 90, September/October issue, p. 54-65.

Biddle S., 2013. "Ending the War in Afghanistan", Foreign Affairs, volume 96, September/October issue, p. 49-58.

CIA World Fact Book, updated 2014. Available at: < https://www.cia.gov/library/ publications/the-world-factbook/geos/af.html > [Accessed 3 February 2015].

Counterinsurgency Field Manual 3-24, 2006. Headquarters Department of the Army, U.S. Available at: $<$ http://www.fas.org/irp/doddir/army/fm3-24.pdf $>$ [Accessed 14 March 2013].

David E. Sanger, 2009. The Inheritance. A New President Confronts the World, Black Swan, Great Britain.

Denoeux G., 2002. “The Forgotten Swamp: Navigating Political Islam”, Middle East Policy, vol. IX, No. 2.

Eikenberry K., 2013. "The Limits of Counterinsurgency Doctrine in Afghanistan", Foreign Affairs, volume 96, September/October issue, p. 59-74.

Galula D., 1964. Counter-Insurgency Warfare: Theory and Practice, Praeger F. publisher, U.S., Available at: < http://louisville.edu/armyrotc/files/Galula\%20 David\%20-\%20Counterinsurgency\%20Warfare.pdf $>$ [Accessed 23 November 2014].

Guest K., 2010. "Dynamic Interplay Between Religion and Armed Conflicts in 
Afghanistan". Available at: <http://www.icrc.org/eng/assets/files/review/2010/ irrc-880-guest.pdf $>$ [Accessed 23 October 2011].

International Crisis Group, The Insurgency in Afghanistan's Heartland, Asia Report No 207, June 2011. Available at: < http://www.crisisgroup.org/en/regions/asia/ south-asia/afghanistan/207-the-insurgency-in-afghanistans-heartland.aspx> [Accessed 27 June 2012].

Kaplan F., 2013. "The End of the Age of Petraeus", Foreign Affairs, volume 92, January/February issue, p. 75-90.

Karzai H., 2014. "I didn't See a War in Afghanistan - I Saw a Conspiracy", an exit interview with Afghan President. Available at: <http://www.theatlantic.com/ international/archive/2014/06/an-exit-interview-with-afghan-presidenthamid-karzai/373199/> [Accessed 4 January 2015].

Katzman K., 2011. "Afghanistan: Politics, Elections and Government Performance“, CRS Report for the Congress. Available at: < http://fpc.state.gov/documents/ organization/155581.pdf $>$ [Accessed 10 October 2011].

Katzman K., 2015. "Afghanistan: Politics, Elections and Government Performance", CRS Report for the Congress. Available at: < https://www.fas.org/sgp/crs/row/ RS21922.pdf> [Accessed 25 March 2015].

Mashal M., 2014. "After Karzai”, The Atlantic, November/December issue. Available at: <http://www.theatlantic.com/features/archive/2014/06/after-karzai/372294/> [Accessed 4 January 2015].

Shurkin M., 2011. Subnational Government in Afghanistan, RAND Corporation, National Defense Research Institute, U.S., p.5-11.

Tanner S., 2009. Afghanistan: A Military History of Afghanistan from Alexander The Great to the War Against the Taliban, Da Capo Press, Philadelphia.

The Constitution of Afghanistan Ratified 26 January, 2004. Available at: < http:// www.afghanembassy.com.pl/afg/images/pliki/TheConstitution.pdf $>$ [Accessed 3 March 2015].

\section{Note}

1 David E. Sanger, The Inheritance. A New President Confronts the World, Black Swan, Great Britain (2009), p. 450. 


\section{About Author}

\section{Andrius BIVAINIS}

He has been serving as an active-duty officer of Lithuanian Land Force since 2007 and has gained the rank of captain. The author holds master's degree in Political Science and diplomacy from the Vytautas Magnus University. Since 2015 he is a Ph. D. student of Political Science at Lithuanian Military Academy. The scope of interests for research is based on security studies and contemporary conflicts' management with detailed concern of Orientalism notions in the development of international relations.

The author has published some articles on conflicts in Afghanistan, Libya and ongoing contemporary crisis in Eastern Europe. The other most relevant publications of the author are these: "On Clausewitzian Challenge in Eastern Europe", Lithuanian Foreign Policy Review, VU TSPMI, "Obscured Baltic-Russia Relations: Where Is the Light Switch in the Tunnel?", Bridges. Lithuanian-American News Journal, March 2015, p. 7-10. andrius.bivainis@mil.lt 